Prepared in cooperation with the New York State Department of Environmental Conservation

\title{
Aquifer Transmissivity in Nassau, Queens, and Kings Counties, New York, Estimated From Specific-Capacity Tests at Production Wells
}

Open-File Report 2020-1108 
Cover. Artistic image derived from figure 1 of this report. 


\section{Aquifer Transmissivity in Nassau, Queens, and Kings Counties, New York, Estimated From Specific-Capacity Tests at Production Wells}

By John H. Williams, Madison Woodley, and Jason S. Finkelstein

Prepared in cooperation with the

New York State Department of Environmental Conservation

Open-File Report 2020-1108 


\title{
U.S. Department of the Interior \\ DAVID BERNHARDT, Secretary
}

\author{
U.S. Geological Survey \\ James F. Reilly II, Director
}

U.S. Geological Survey, Reston, Virginia: 2020

For more information on the USGS - the Federal source for science about the Earth, its natural and living resources, natural hazards, and the environment-visit https://www.usgs.gov or call 1-888-ASK-USGS.

For an overview of USGS information products, including maps, imagery, and publications, visit https://store.usgs.gov/.

Any use of trade, firm, or product names is for descriptive purposes only and does not imply endorsement by the U.S. Government.

Although this information product, for the most part, is in the public domain, it also may contain copyrighted materials as noted in the text. Permission to reproduce copyrighted items must be secured from the copyright owner.

Suggested citation:

Williams, J.H., Woodley, M., and Finkelstein, J.S., 2020, Aquifer transmissivity in Nassau, Queens, and Kings Counties, New York, estimated from specific-capacity tests at production wells: U.S. Geological Survey Open-File Report 2020-1108, 7 p., https://doi.org/10.3133/ofr20201108.

Associated data for this publication:

U.S. Geological Survey, 2020, USGS water data for the Nation: U.S. Geological Survey National Water Information System database, https://doi.org/10.5066/F7P55KJN.

ISSN 2331-1258 (online) 


\section{Contents}

Abstract

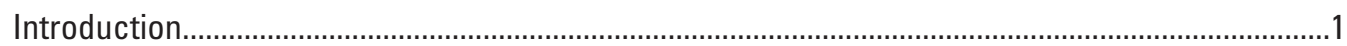

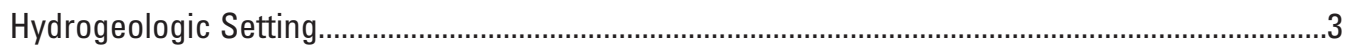

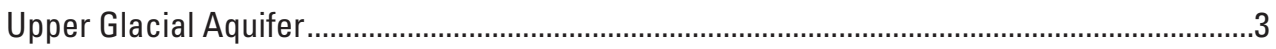

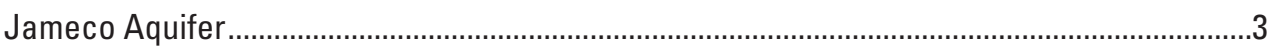

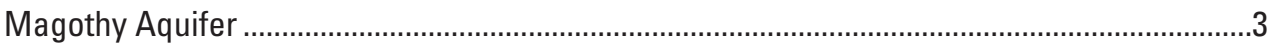

Lloyd Aquifer ....................................................................................................................

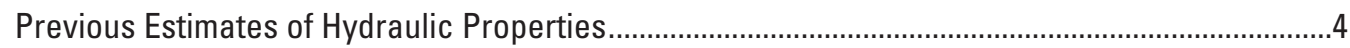

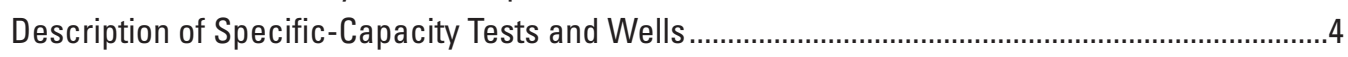

Estimation Method and Limitations ........................................................................................

Estimated Transmissivities of Selected Production Wells...................................................................5

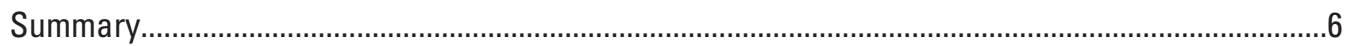

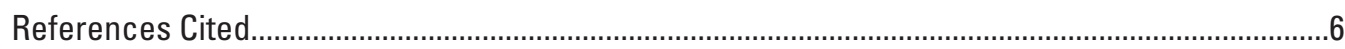

\section{Figures}

1. Map showing generalized surficial geology and location of selected production wells with specific-capacity data in Nassau, Queens, and Kings Counties, New York

2. Generalized hydrogeologic section of principal aquifers on Long Island, New York; modified from Smolensky and others (1989)

3. Statistical box plot of transmissivity estimated from specific-capacity tests of selected production wells by principal aquifer, Nassau, Queens, and Kings Counties, Long Island, New York.

\section{Tables}

1. Summary statistics of transmissivity estimated from specific-capacity tests of selected production wells by principal aquifer in Nassau, Queens, and Kings Counties, Long Island, New York...

\section{Conversion Factors}

\begin{tabular}{lcl}
\hline \multicolumn{1}{c}{ Multiply } & \multicolumn{1}{c}{ By } & \multicolumn{1}{c}{ To obtain } \\
\hline inch $(\mathrm{in})$. & 25.4 & millimeter $(\mathrm{mm})$ \\
foot $(\mathrm{ft})$ & 0.3048 & meter $(\mathrm{m})$ \\
mile $(\mathrm{mi})$ & 1.609 & kilometer $(\mathrm{km})$ \\
gallon per minute $(\mathrm{gal} / \mathrm{min})$ & 0.06309 & liter per second $(\mathrm{L} / \mathrm{s})$ \\
foot squared per day $(\mathrm{ft} 2 / \mathrm{d})$ & 0.09290 & meter squared per day $(\mathrm{m} 2 / \mathrm{d})$ \\
\hline
\end{tabular}




\title{
Datum
}

Vertical coordinate information is referenced to the North American Vertical Datum of 1988 (NAVD 88).

Horizontal coordinate information is referenced to the North American Datum of 1983 (NAD 83).

Altitude, as used in this report, refers to distance above the vertical datum.

\section{Abbreviations}

\author{
NWIS National Water Information System \\ NYSDEC New York State Department of Environmental Conservation \\ USGS U.S. Geological Survey
}




\title{
Aquifer Transmissivity in Nassau, Queens, and Kings Counties, New York, Estimated From Specific-Capacity Tests at Production Wells
}

\author{
By John H. Williams, Madison Woodley, and Jason S. Finkelstein
}

\section{Abstract}

As part of a cooperative effort between the U.S. Geological Survey and the New York State Department of Environmental Conservation to evaluate the sustainability of Long Island's sole-source aquifer system, the transmissivities of four aquifers were estimated from specific-capacity tests at 447 production wells in Nassau, Queens, and Kings Counties on Long Island, New York. The specific-capacity test data, which included pumping rate, pumping duration, and drawdown, were obtained from published and unpublished records of driller-reported acceptance tests collected at production wells screened in the upper glacial, Jameco, Magothy, or Lloyd aquifers. Pumping rates from the production wells during the tests generally were greater than 400 gallons per minute and ranged up to 1,800 gallons per minute. Pumping duration generally was 8 hours or more. Transmissivities were estimated from the specific-capacity data by the CooperJacob approximation of the Theis equation. The transmissivity estimates are considered rough approximations because the aquifers do not meet the ideal assumptions of the method, well losses and partial penetration were not accounted for, and aquifer storage coefficients were not known but were only estimated from available data.

The transmissivities estimated from production wells screened in the upper glacial aquifer in the outwash plain south of the moraine generally were greater than those of the aquifer north of the moraine. The transmissivities estimated from the wells screened in the upper glacial aquifer south of the moraine typically ranged (as defined by the 10th and 90th percentiles) from 3,800 to 15,000 feet squared per day $\left(\mathrm{ft}^{2} / \mathrm{d}\right)$, with a median value of $7,300 \mathrm{ft} 2 / \mathrm{d}$. The transmissivities estimated from the wells screened in the upper glacial aquifer north of the moraine typically ranged from 2,100 to $7,400 \mathrm{ft}^{2} / \mathrm{d}$, with a median value of $4,400 \mathrm{ft}^{2} / \mathrm{d}$. The Jameco aquifer generally had the highest estimated transmissivities of all the aquifers analyzed. The estimated transmissivities for the Jameco aquifer typically ranged from 5,500 to $43,000 \mathrm{ft} 2 / \mathrm{d}$, with a median value of $16,000 \mathrm{ft}^{2} / \mathrm{d}$. The Magothy and Lloyd aquifers had similar estimated transmissivities. The transmissivities estimated for the Magothy aquifer typically ranged from 2,700 to $13,000 \mathrm{ft}^{2} / \mathrm{d}$, with a median of $7,100 \mathrm{ft}^{2} / \mathrm{d}$. The estimated transmissivities of the Lloyd typically ranged from 3,000 to $14,000 \mathrm{ft}^{2} / \mathrm{d}$, with a median of $7,200 \mathrm{ft}^{2} / \mathrm{d}$.

\section{Introduction}

In 2016, the U.S. Geological Survey (USGS) began a cooperative study with the New York State Department of Environmental Conservation (NYSDEC) to evaluate the sustainability of Long Island's sole-source aquifer system through hydrogeologic mapping, monitoring of groundwater quality and levels, and construction of a groundwater-flow model. As part of the groundwater sustainability study, specific-capacity test data from published and unpublished records were analyzed to estimate transmissivity of selected production wells in Nassau, Queens, and Kings Counties on Long Island, New York (fig. 1). 


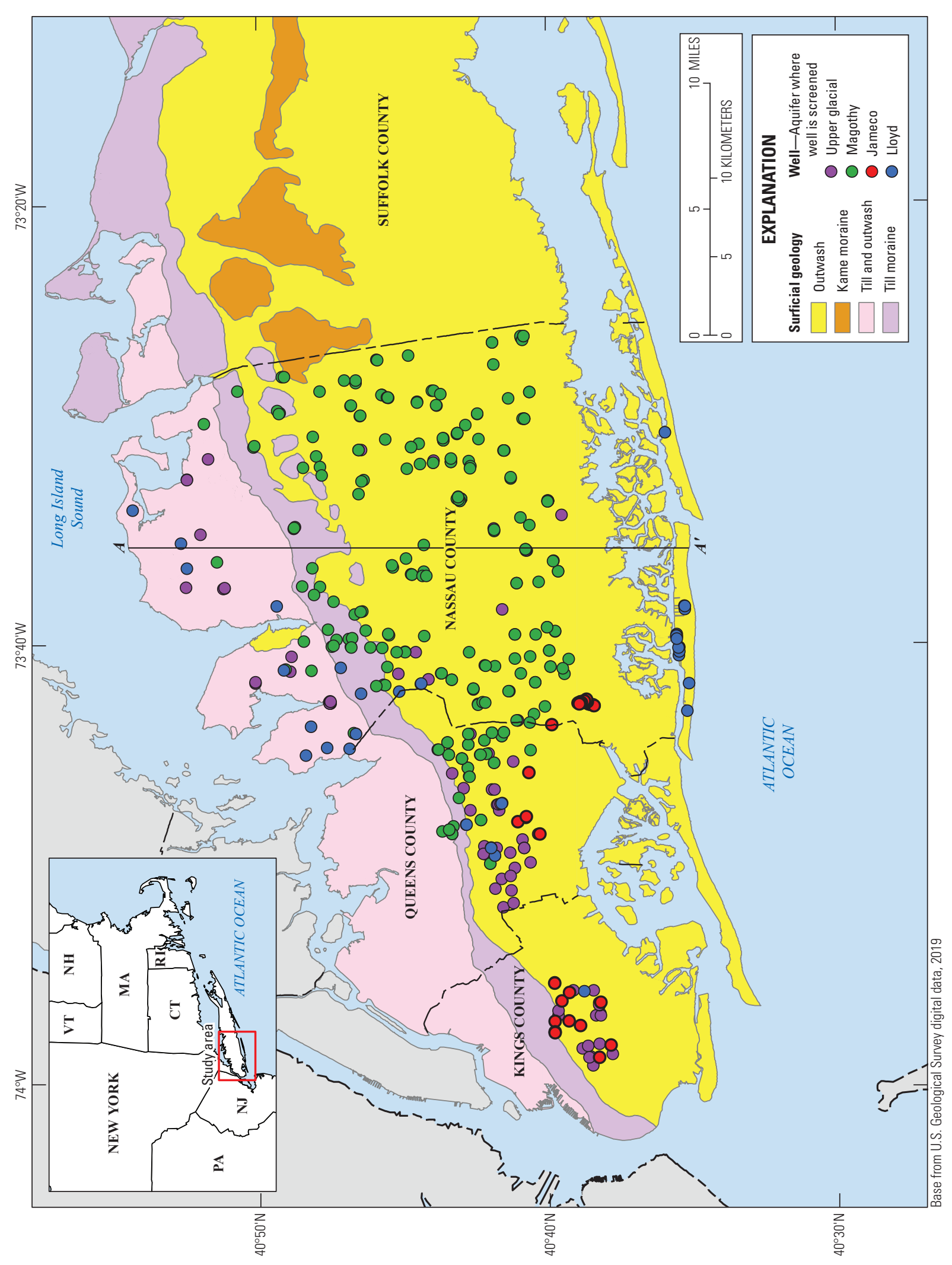

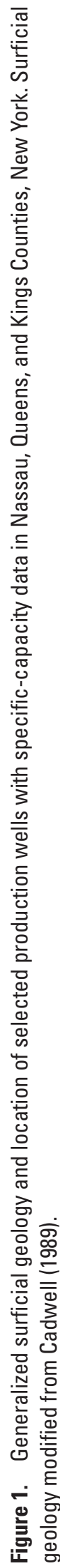




\section{Hydrogeologic Setting}

The hydrogeologic setting of Long Island is presented in Smolensky and others (1989). The principal aquifers are the upper glacial, Jameco, Magothy, and Lloyd. The hydrogeologic characteristics of the four aquifers are summarized below.

\section{Upper Glacial Aquifer}

Till, kame, outwash, lacustrine, and marine sediments deposited during the Pleistocene epoch form the upper glacial aquifer of Long Island. Till is a poorly permeable unsorted mixture of clay, silt, sand, and stones deposited beneath and adjacent to glacial ice. Kame sediments are variably sorted ice-contact deposits of sand, gravel, and silt that range in permeability. Outwash sediments consist of well-sorted sand and gravel deposited in front of glacial ice that are moderately to highly permeable. Moraines, formed by a heterogeneous mix of till and kame sediments, mark the southernmost extent of glacial ice on Long Island (fig. 1). The most extensive deposits of outwash underlie the southern part of Long Island in front of the moraines. Outwash deposits are present with the till north of the moraines but are less extensive. Lacustrine deposits, present mostly in central and eastern Long Island, and marine deposits, locally present along the south shore, are dominantly fine-grained deposits with poor permeability but contain thin local lenses of sand and gravel that are moderately permeable. The upper glacial aquifer is in hydraulic contact with the Magothy aquifer except along the southern shore where the Gardiners clay restricts vertical flow between the aquifers (fig. 2).

\section{Jameco Aquifer}

The Jameco aquifer, formed during the Pleistocene epoch, lies unconformably beneath and is confined by the Gardiners clay on the southern shore of Nassau, Queens, and Kings Counties (fig. 2). The Jameco aquifer is a fluvial deposit of fine to coarse sand and gravel deposited in channels eroded into the underlying Magothy deposits. The Jameco deposits are up to 200 feet (ft) thick and are moderately to highly permeable.

\section{Magothy Aquifer}

The Magothy aquifer, formed during the Cretaceous period, extends throughout most of Long Island. In Nassau, Queens, and Kings Counties, it lies unconformably beneath the upper glacial aquifer in the northern and central areas and the Jameco aquifer and Gardiners clay on the southern shore (fig. 2). The Magothy deposits are up to $600 \mathrm{ft}$ thick and consist of alternating beds of sand, silt, and clay with gravel common in the basal zone.

$\boldsymbol{A}$

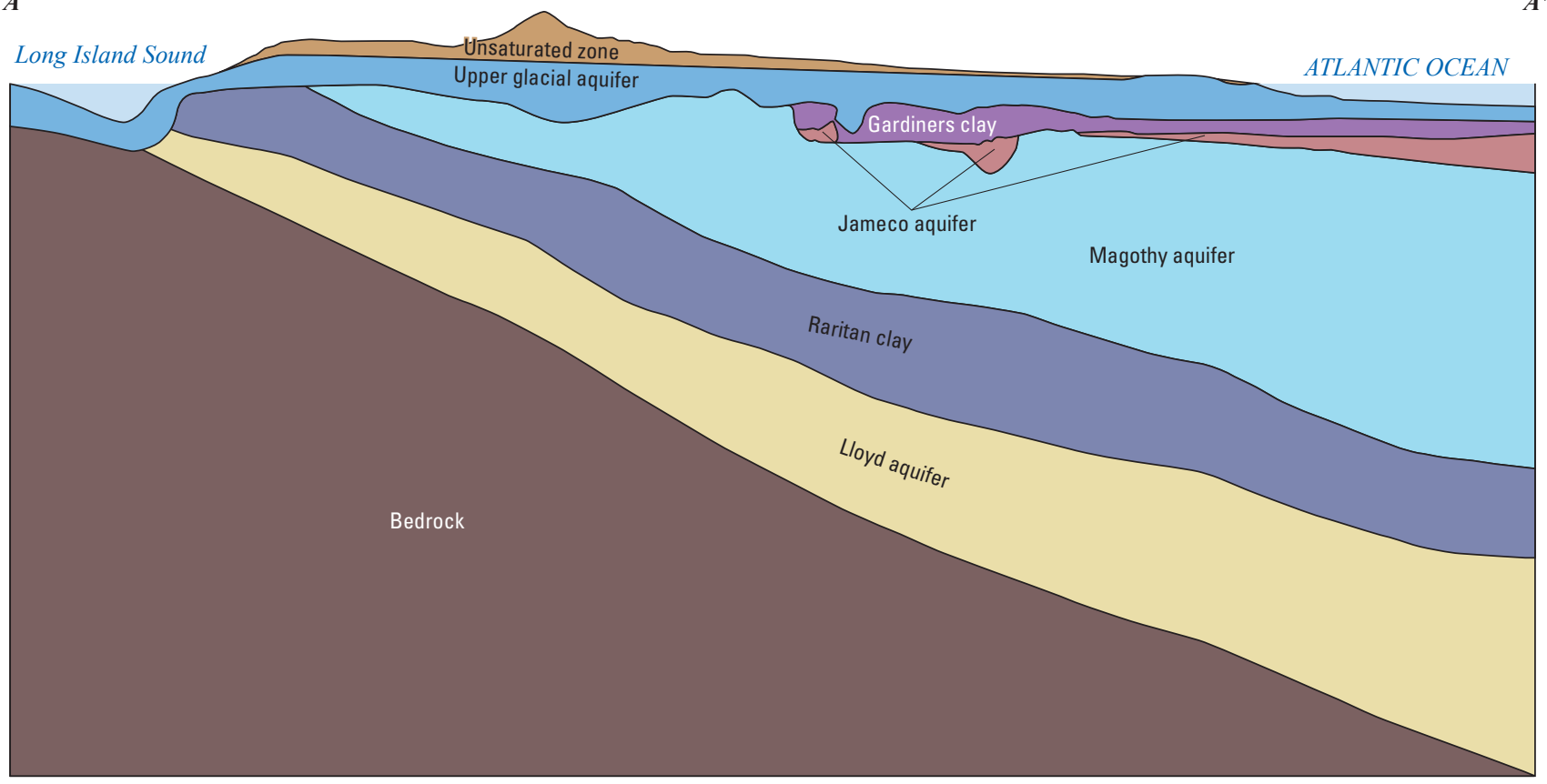

NOT TO SCALE

Figure 2. Generalized hydrogeologic section of principal aquifers on Long Island, New York; modified from Smolensky and others (1989). Location of cross section shown on figure 1. 


\section{Lloyd Aquifer}

The Lloyd aquifer of Cretaceous age lies conformably beneath and is confined by the Raritan clay (fig. 2). The Lloyd aquifer rests unconformably on bedrock throughout most of Long Island and is up to $400 \mathrm{ft}$ thick. The Lloyd aquifer consists of fine to coarse sand and gravel with lenses of silty clay.

\section{Previous Estimates of Hydraulic Properties}

Transmissivity and hydraulic conductivity estimates for aquifers on Long Island from selected areal groundwater appraisals and aquifer-test site studies were previously summarized by McClymonds and Franke (1972). These estimates of aquifer hydraulic properties were derived from specific-capacity tests (pumping rate and drawdown data) and aquifer tests (single- and multiple-well time-drawdown data) through analytical methods. McClymonds and Franke (1972) also published statistical summaries and contoured maps of transmissivity and hydraulic conductivity of the aquifers based on an analysis of specific capacities, screen lengths, and lithologic logs from production-well completion reports. Lindner and Reilly (1982), Aronson and others (1983), Prince and Schneider (1989), and Cartwright (1997) used numerical radial-flow models, and Misut and Busciolano (2009) used analytical models to estimate hydraulic properties at selected aquifer-test sites on Long Island. Estimates of aquifer hydraulic properties from these previous studies associated with specific well sites are available from the USGS National Water Information System database (NWIS; U.S. Geological Survey, 2020a) and can be viewed through the Aquifer Test Locator graphical user interface (U.S. Geological Survey, 2020b).

\section{Description of Specific-Capacity Tests and Wells}

Specific-capacity test and well-construction data were compiled for 447 tested well sites from a previously published compilation by Chu (1996) for Kings and Queens Counties and from unpublished paper records for Nassau and western Suffolk Counties. Approximately half of the tested well sites were screened in the Magothy aquifer, and one-quarter were screened in the upper glacial aquifer in the outwash plain south of the moraine deposits. The specific-capacity test and well-construction data, which included test date, pumping rate and duration, water levels before and during pumping, screen length and diameter, and depth of top and bottom of the screened interval, were sourced from completion reports of production well-acceptance tests conducted from 1919 to 1982 (NYSDEC, written commun., 1982). The specific-capacity test and well-construction data compiled for this study were added to the well location, altitude, and aquifer data previously entered in NWIS; the NWIS data can be mapped through the Aquifer Test Locator graphical user interface (U.S. Geological Survey, 2020b).

The production wells typically were screened in the more transmissive part of the aquifer that was penetrated during drilling. Well-screen depths were as shallow as $20 \mathrm{ft}$ below land surface in the upper glacial aquifer to as deep as $1,280 \mathrm{ft}$ below land surface in the Lloyd aquifer on the barrier-beach islands. Median well-screen lengths were $20 \mathrm{ft}$ in the upper glacial aquifer north of the moraine, $29 \mathrm{ft}$ in the upper glacial aquifer south of the moraine, $20 \mathrm{ft}$ in the Jameco aquifer, $52 \mathrm{ft}$ in the Magothy aquifer, and $60 \mathrm{ft}$ in the Lloyd aquifer. Pumping rates from the production wells during the tests generally were greater than 400 gallons per minute $(\mathrm{gal} / \mathrm{min})$ and ranged up to $1,800 \mathrm{gal} / \mathrm{min}$. Pumping durations generally were 8 hours or more.

\section{Estimation Method and Limitations}

The transmissivities of the aquifers at the selected production wells were estimated from the specific-capacity test and well-construction data following the method of Bradbury and Rothschild (1985). The method applies the Cooper-Jacob approximation of the Theis (1935) equation:

$$
T=\frac{Q}{4 \pi\left(s_{m}-s_{w}\right)}\left[\ln \left(\frac{2.25 T t}{r_{w}^{2} S}\right)+2 s_{p}\right],
$$

where

$T$ is transmissivity, in feet squared per day;

$Q \quad$ is pumping rate, in cubic feet per day;

$s_{m} \quad$ is measured drawdown, in feet;

$s_{w} \quad$ is well loss, in feet;

$t$ is time since pumping began, in days;

$r_{\mathrm{w}} \quad$ is effective wellbore radius, in feet;

$S \quad$ is aquifer storage coefficient (dimensionless); and

$s_{p} \quad$ is the partial-penetration correction factor (dimensionless).

The iterative solution of equation 1 is based on an initial guess of $T$, and $Q, s_{m}$, and $t$ from the specific-capacity test. The method assumes that the tested aquifer is confined, nonleaky, homogeneous, and isotropic; flow is radial to the pumping well; well loss is known; aquifer thickness is known; and the storage coefficient of the aquifer is known. The transmissivities estimated in this study are considered to be rough approximations because the aquifers do not meet these ideal assumptions, well losses were not considered $\left(s_{w}=0\right)$, the partial-penetration correction was not applied $\left(s_{p}=0\right)$, and storage coefficients $(S)$ were approximated. Step-drawdown tests that are used to determine well-loss coefficients were not available for the production wells. Because of high 
pumping rates, well losses may be substantial in some wells tested, causing reduced specific capacities and estimates of transmissivity.

The degree of partial penetration is dependent on the length of the well screen in relation to the thickness of the aquifer tested. Although well-screen lengths were available, drawdown data in surrounding observation wells and detailed lithologic logs that are needed to determine the effective aquifer thickness were lacking at the production-well test sites. Not applying the partial-penetration correction used in the Bradbury and Rothschild (1985) method to the partially penetrating production wells in this study should have resulted in lower transmissivity estimates than if the partial-penetration correction had been applied. Also, the partial-penetration correction factor used in the method assumes that the horizontal hydraulic conductivity is equal to the vertical hydraulic conductivity, which is not the case for the aquifers of Long Island. Because of the sedimentary depositional environments of the aquifers on Long Island, horizontal hydraulic conductivity is at least an order of magnitude greater than vertical hydraulic conductivity in the aquifers, with the Magothy aquifer displaying the greatest vertical anisotropy (Smolensky and others, 1989). Applying the partial-penetration correction to a vertically anisotropic aquifer should result in overestimation of transmissivity values.

Storage coefficients for the aquifers at the productionwell test sites were not known but were approximated based on published values from Lindner and Reilly (1982), Prince and Schneider (1989), Cartwright (1997), and Misut and Busciolano (2009). Storage values used in the present analysis were as follows: 0.15 for wells screened within $200 \mathrm{ft}$ of the water table in the unconfined upper glacial and Magothy aquifers; 0.003 for wells screened $200 \mathrm{ft}$ below the water table in the semiconfined upper glacial and Magothy aquifers; and $2 \times 10^{-5}$ for the confined Jameco, Magothy, and Lloyd aquifers. Storage is one of the less sensitive parameters; for example, using an unconfined storage value for a semiconfined aquifer would decrease the transmissivity estimate by less than 20 percent, whereas, conversely, using a confined storage value would increase the transmissivity estimate by not more than the same percentage.

\section{Estimated Transmissivities of Selected Production Wells}

The estimated transmissivities of the selected production wells and the specific-capacity and well-construction data are available from the NWIS database and are viewable through the Aquifer Test Locator graphical user interface (U.S. Geological Survey, 2020b). The estimated transmissivities at the production wells of the upper glacial aquifer in the outwash plain south of the moraine were generally greater than those north of the moraine (fig. 3; table 1). The estimated transmissivities at the wells in the upper glacial aquifer

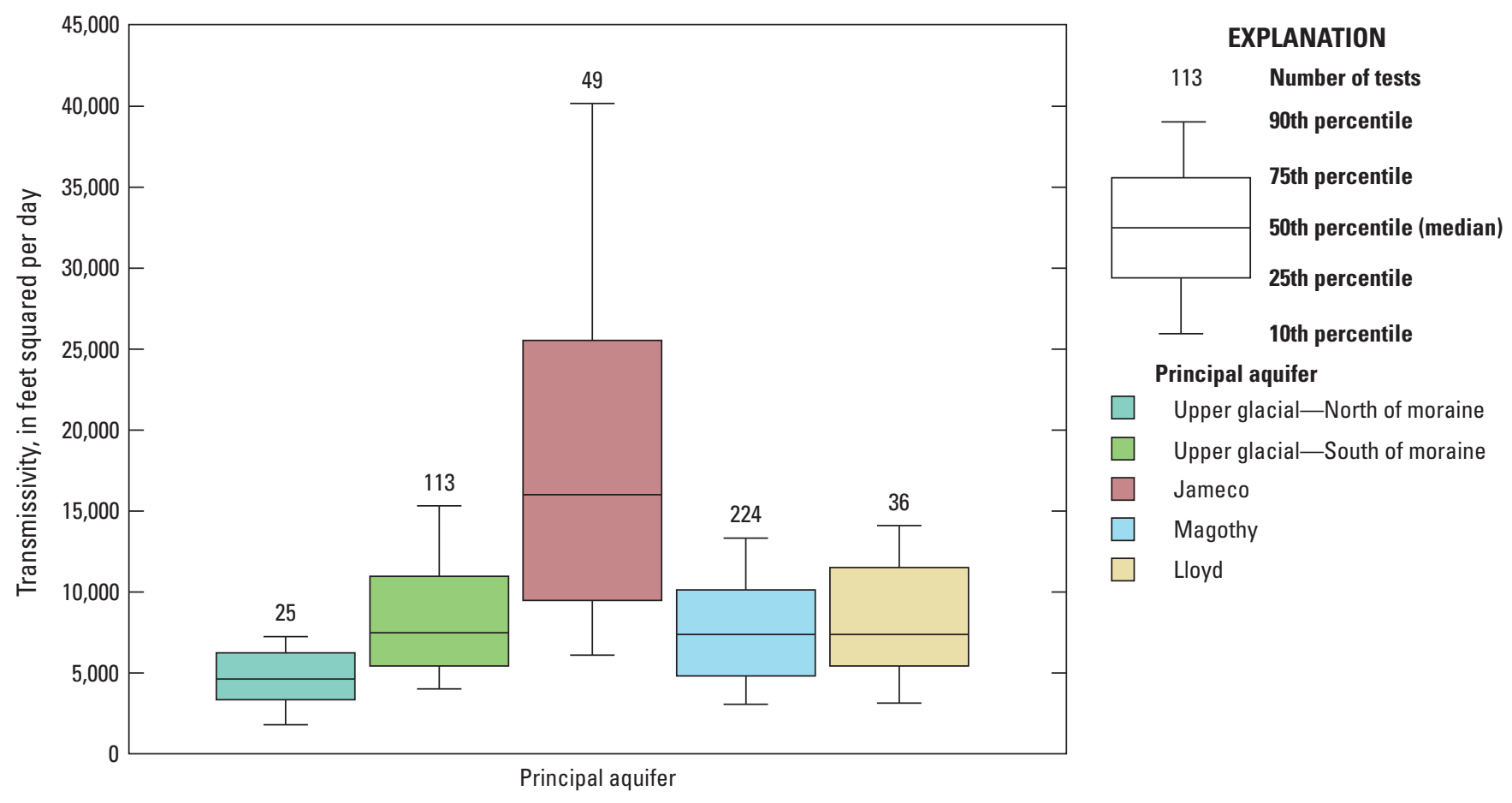

Figure 3. Statistical box plot of transmissivity estimated from specific-capacity tests of selected production wells by principal aquifer, Nassau, Queens, and Kings Counties, Long Island, New York. 
Table 1. Summary statistics of transmissivity estimated from specific-capacity tests of selected production wells by principal aquifer in Nassau, Queens, and Kings Counties, Long Island, New York.

\begin{tabular}{lccrrrrr}
\hline \multirow{2}{*}{ Aquifer } & Number of & Median screen length, & \multicolumn{5}{c}{ Transmissivity, by percentile, in feet squared per day } \\
\cline { 5 - 9 } & in feet & 20 & 2,100 & 3,600 & 4,400 & 5,700 & 7,400 \\
\hline Upper glacial, north of moraine & 25 & 29 & 3,800 & 5,300 & 7,300 & 11,000 & 15,000 \\
Upper glacial, south of moraine & 113 & 20 & 5,500 & 9,700 & 16,000 & 25,000 & 43,000 \\
Jameco & 49 & 52 & 2,700 & 4,800 & 7,100 & 9,900 & 13,000 \\
Magothy & 224 & 60 & 3,000 & 4,900 & 7,200 & 11,000 & 14,000 \\
Lloyd & 36 & & & & & &
\end{tabular}

on the outwash plain south of the moraine typically ranged (as defined by the 10th and 90th percentiles) from 3,800 to 15,000 feet squared per day ( $\left.\mathrm{ft}^{2} / \mathrm{d}\right)$ and had a median value of $7,300 \mathrm{ft}^{2} / \mathrm{d}$. The estimated transmissivities at the wells in the upper glacial aquifer north of the moraine deposits typically ranged from 2,100 to $7,400 \mathrm{ft}^{2} / \mathrm{d}$ and had a median value of $4,400 \mathrm{ft} 2 / \mathrm{d}$. Production wells in the Jameco aquifer generally had the greatest estimated transmissivities of all the aquifers. The estimated transmissivities at the production wells in the Jameco aquifer typically ranged from 5,500 to 43,000 ft2/d and had a median value of $16,000 \mathrm{ft}^{2} / \mathrm{d}$. The estimated transmissivities of the production wells in the Magothy and Lloyd aquifers generally were similar. The estimated transmissivities at the wells in the Magothy aquifer typically ranged from 2,700 to $13,000 \mathrm{ft}^{2} / \mathrm{d}$ and had a median of 7,100 ft2/d. The estimated transmissivities at the wells in the Lloyd aquifer typically ranged from 3,000 to $14,000 \mathrm{ft}^{2} / \mathrm{d}$ and had a median of $7,200 \mathrm{ft}^{2} / \mathrm{d}$.

\section{Summary}

As part of a cooperative effort between the

U.S. Geological Survey and the New York State Department of Environmental Conservation to evaluate the sustainability of Long Island's sole-source aquifer system, the transmissivities of 447 production wells in Nassau, Queens, and Kings Counties on Long Island, New York, were estimated from specific-capacity tests. The specific-capacity test data, which included pumping rate, pumping duration, and drawdown, were obtained from published and unpublished records of driller-reported acceptance tests collected at production wells screened in the upper glacial, Jameco, Magothy, or Lloyd aquifers. Median well-screen lengths ranged from less than $30 \mathrm{ft}$ in the upper glacial and Jameco aquifers to more than $50 \mathrm{ft}$ in the Magothy and Lloyd aquifers. Pumping rates from the production wells during the tests generally were greater than 400 gallons per minute and ranged up to 1,800 gallons per minute. Pumping duration generally was 8 hours or more.

Transmissivity was estimated from the specific-capacity data by the Cooper-Jacob approximation of the Theis equation. The transmissivity values are considered rough approximations because the aquifers do not meet the ideal assumptions of the method, well losses and partial penetration were not accounted for, and storage was not known but estimated from available data.

The estimated transmissivities at the production wells in the upper glacial aquifer south of the moraine generally were greater than those of the aquifer north of the moraine. Wells in the Jameco aquifer generally had greater estimated transmissivities than those in the other aquifers. Wells in the Magothy and Lloyd aquifers had similar estimated transmissivities. The median aquifer transmissivities were $4,400 \mathrm{ft}^{2} / \mathrm{d}$ for the upper glacial aquifer north of the moraine, $7,300 \mathrm{ft} 2 / \mathrm{d}$ for the upper glacial aquifer south of the moraine, $16,000 \mathrm{ft}^{2} / \mathrm{d}$ for the Jameco aquifer, 7,100 $\mathrm{ft}^{2} / \mathrm{d}$ for the Magothy aquifer, and $7,200 \mathrm{ft} 2 / \mathrm{d}$ for the Lloyd aquifer.

\section{References Cited}

Aronson, D.A., Lindner, J.B., and Katz, B.G., 1983, Geohydrology of the Meadowbrook artificial-recharge site at East Meadow, Nassau County, New York: U.S. Geological Survey Water-Resources Investigations Report 82-4084, 44 p. [Also available at https://doi.org/ 10.3133/wri824084.].

Bradbury, K.R., and Rothschild, E.R., 1985, A computerized technique for estimating the hydraulic conductivity of aquifers from specific capacity data: Ground Water, v. 23, no. 2, p. 240-246. [Also available at https://doi.org/10.1111/ j.1745-6584.1985.tb02798.x.].

Cadwell, D.H., 1989, Surficial geologic map of New YorkLower Hudson Sheet: New York State Museum Map and Chart Series 40, 1 sheet, scale 1:250,000. [Also available at http:/www.nysm.nysed.gov/common/nysm/files/surf lowerhudson.jpg.]

Cartwright, R.A., 1997, Hydrogeologic-setting classification for Suffolk County, Long Island, New York; with results of selected aquifer-test analyses: U.S. Geological Survey Open-File Report 96-457, 18 p. [Also available at https://doi.org/10.3133/ofr96457.]. 
Chu, A., 1996, Results of specific-capacity tests in Kings and Queens Counties, New York, 1919-82: U.S. Geological Survey Open-File Report 96-575, 12 p. [Also available at https://doi.org/10.3133/ofr96575.].

Lindner, J.B., and Reilly, T.E., 1982, Analysis of three tests of the unconfined aquifer in southern Nassau County, Long Island, New York: U.S. Geological Survey Water-Resources Investigations Report 82-4021, 46 p. [Also available at https://doi.org/10.3133/wri824021.].

McClymonds, N.E., and Franke, O.L., 1972, Water transmitting properties of aquifers on Long Island, New York: U.S. Geological Survey Professional Paper 627-E, 24 p. [Also available at https://doi.org/10.3133/pp627E.].

Misut, P.E., and Busciolano, R., 2009, Hydraulic properties of the Magothy and upper glacial aquifers at Centereach, Suffolk County, New York: U.S. Geological Survey Scientific Investigations Report 2009-5190, 23 p. [Also available at https://doi.org/10.3133/sir20095190.].
Prince, K.R., and Schneider, B.J., 1989, Estimation of hydraulic characteristics of the upper glacial and Magothy aquifers at East Meadow, New York, by use of aquifer tests: U.S. Geological Survey Water-Resources Investigations Report 87-4211, 43 p. [Also available at https://doi.org/ 10.3133/wri874211.].

Smolensky, D.A., Buxton, H.T., and Shernoff, P.K., 1989, Hydrologic framework of Long Island, New York: U.S. Geological Survey Hydrologic Investigations Atlas 709, 3 sheets, scale 1:250,000. [Also available at https://doi.org/10.3133/ha709.]

Theis, C.V., 1935, The relation between the lowering of the piezometric surface and the rate and duration of discharge of wells using groundwater storage-Eos, American Geophysical Union: Transactions, v. 16, p. 519-524.

U.S. Geological Survey, 2020a, USGS water data for the Nation: U.S. Geological Survey National Water Information System database, accessed May 8, 2020, at https://doi.org/ 10.5066/F7P55KJN.

U.S. Geological Survey, 2020b, Aquifer test locator: U.S. Geological Survey web page, accessed May 8, 2020, at https://ny.water.usgs.gov/maps/aq-test/. 

For more information about this report, contact: Director, New York Water Science Center

U.S. Geological Survey

425 Jordan Road

Troy, NY 12180-8349

dc_ny@usgs.gov

(518) 285-5602

or visit our website at

https://www.usgs.gov/centers/ny-water

Publishing support provided by the

Pembroke Publishing Service Center 


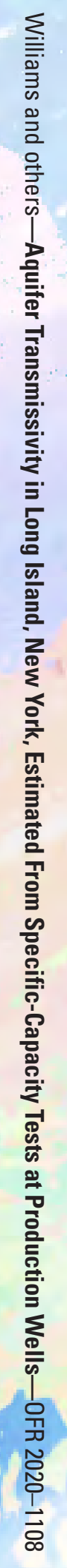

